\title{
Socialt arbete och utvärdering
}

Ungefär samtidigt som jag planerade detta temanummer av Socialvetenskaplig tidskrift läste jag om dramatiska förhållanden, framkallade av ett hormonbaserat preparat, diethylstilboestrol (DES) som använts för att motverka missfall hos kvinnor. Under 1940--60-talen har uppskattningsvis tre till sex miljoner kvinnor ordinerats detta preparat. I vissa länder användes det fram till 1980-talets första år. I de fem första av åtta studier som genomfördes för att studera preparatets effektivitet användes en retrospektiv och matchad forskningsmetod därkvinnor som använtDESjämfördes med kvinnor som inte använt preparatet.

Samtliga studier med denna metod visade att DES var ett framgångsrikt preparat för förebyggandet av missfall. Chansen att fortsätta graviditeten och föda levande barn var dubbelt så hög bland behandlingsgruppen. Sextiofem procent av kvinnorna $i$ behandlingsgruppen hade levande födda spädbarn medan andelen levande födda spädbarn i »kontrollgruppen« var trettiotvå procent. De tre övriga studier som genomfördes hade en prospektiv experimentell forskningsdesign. Kvinnor med missfallsrisk randomiserades till behandlings- respektive kontrollgrupper; randomiseringen baserades på kvinnornas läkares bedömning av osäkerheten i DES användningen.

Forskningsresultaten beträffande DES effektivitet var mycket annorlunda i dessa tre studier: det kunde inte hittas någon effekt vad gäller chansen att föda levande spädbarn. Senare har dessa studier fătt stor betydelse när det började visa sig att döttrar till DES användare rapporterades utveckla en sällsynt variant av vaginal cancer. Såväl döttrar som söner till dessa kvinnor rapporterades dessutom utveckla andra allvarliga sjukdomar. Det kom också att visa sig att DES användarna själva hade ökad grad av bröstcancerfall. Det var uppenbart att DES inte bara var effektlöst mot missfall, utan hade också långsiktigt skadliga effekter (Oakley 2000, 308). Användningen av DES har avbrutits.

DES forskningen visar ett generellt problem: interventioner med goda syften kan ha icke önskade och skadliga effekter!

Det finns också exempel på sociala interventioner med skadliga effekter; en av de mest kända är kanske CambridgeSomervillestudien om rådgivningsprogram för unga flickor och pojkar. Den upprepade uppföljningen av effekterna av rådgivning till ungdomar i riskzon visade att de som hade fătt stöd av socialarbetare hade mer brottslighet än dem som inte hade exponerats för rådgivning (McCord 1978).

Studier av interventioner i socialt arbete är ett underutvecklat område (Macdonald 1998). Litteraturöversikter i tidskrifter för forskning i socialt arbete är mycket ofta narrativa, anger inte kriterier för inkludering och exkludering av litteratur, och ger samma vikt åt studier som genomförts med 
olika forskningsdesigner eller som har olika vetenskaplig styrka.

Det urval av studier som presenteras i detta temanummer måste värderas mot den bakgrund som här antyds: att utvärdering av interventioner som är riktade mot människors hälsa och sociala välbefinnande kan ha livsviktig betydelse, och att utvärdering av interventioner $\mathrm{i}$ socialt arbete har just börjat sin långa vandring mot ett bättre tillstånd där åtminstone skadliga effekter av stora interventionsprogram gjorts kända.

I temanumret möts bidrag från två praktik- och kunskapstraditioner: nämligen utvärdering och socialt arbete. Typiskt har både traditionerna egenpraktik och gör anspråk på teoretiska (i bästa fall disciplinära) fält. Huvudansatsen i detta nummer är således att belysa frågor som samtidigt förenar insatser från både traditionerna.

Oavsett om man vill studera effekterna av interventioner i socialt arbete eller andra aspekter som till exempel interventioners förlopp och processer blir det nödvändigt att vända sig till utvärderingsforskningen för val av lämpliga utgångspunkter, teorier, och definitivt för val av metoder och metodologiskt stöd.

Utvärdering som praktik har sedan senare delen 1950-talet fått luft under vingarna. Huvudsakligen i USA har vissa händelser burit fram utvärderingsforskningen. Dessa inkluderar utvärdering av försvarssystem som lanserades i kapprustningen mot kommunismen och Sovjetunionen (1950-talet); lansering av nya lagar mot diskriminering och för positiv diskriminering av etniska minoriteter och handikappade samt det så kallade Great
Society programmen för reducering av fattigdom och sociala problem (1960-talet); den federala statens strävan att säkerställa bättre användning av skattemedel som beviljats organisationer och institutioner (1970-talet); program för att höja USAs internationella kompetens inom olika verksamhetsområden (1980-talet). Och senast under 1990-talet såväl i USA som i andra delar av världen har utvärderingsforskningen kommit till nytta för att säkra och öka kvalitet, träffsäkerhet och rättvisa i service inom ett antal verksamhetsområden som hälsovård, socialtjänst och skola.

Reformer inom skolan har varit det första och under lång tid huvudsakliga studieobjektet för svensk utvärderingsverksamhet inom det sociala området (Franke-Wikberg och Lundgren 1980). Utöver utvärdering av svenska skolreformer har utvärdering som professionell verksamhet i Sverige varit begränsad, särskilt mätt $i$ termer av det som sedan lång tid tillbaka pågick i USA. Statsvetaren Evert Vedungs bok Utvärdering $\mathrm{i}$ politik och förvaltning som först kom ut i början av 1990-talet var det första tunga bidrag som på ett allmänt plan gav ansikte till utvärderingsforskningen i Sverige (Vedung 1991 och på engelska Vedung 1997). Det första omfattande försöket att $i$ Sverige relatera socialt arbete och modern utvärderingsforskning publicerades i Scandinavian Journal of Social Welfare år 1998.

Det bör i detta sammanhang nämnas att det finns en växande diskurs om vikten att basera praktiskt socialt arbete på empiriskt prövade kunskaper - ett förhållande som torde vara väl känt för många av denna tidskrifts läsare. Debatten förs till exempel inom ramen för den amerikanska

Socialt arbete och utvärdering 
organisationen, Society for Social Work and Research (en motsvarighet till FORSA i Sverige och andra nordiska länder) och den växande Campbell Collaboration för utveckling och distribution av systematiska forskningssynteser bland annat i socialt arbete (http://www.campbellcollaboration. org). I Sverige har Socialstyrelsen nyligen utrett kärnfrågorna kring empiriskt baserat socialt arbete på uppdrag av regeringen (Socialstyrelsen 2000).

Urvalet av artiklar i föreliggande temanummer har gjorts mot bakgrund av den internationella utvecklingen $\mathrm{i}$ utvärderingsforskningen och debatten om kunskapsbaserat socialt arbete. På ett begränsat utrymme kan naturligtvis inte alla väsentliga teman täckas. De artiklar som nu presenteras på svenska har valts med ledning av tre kriterier: översikt, exemplifiering och utvärderingsforskningens spetsfrågor.

I ett temanummer av en tidskrift som annars bevakar ett brett empiriskt och teoretiskt fält som socialt arbete är det viktigt att ge läsaren en översiktlig bild av utvärdering som professionell verksamhet.

På ett sätt kan man hävda att flera artiklar tillsammans ger en översiktlig bild av fältet. Mer specifikt, artiklarna om utvärdering som disciplinär verksamhet och om utvärderingsmodeller fyller detta syfte. Framför allt finns en djungel av utvärderingsmodeller som alla betonar någon aspekt eller några aspekter av hur man bör utvärdera insatser och program. En övergripande sammanfattning av utvärderingsmodeller är ett utmärkt sätt att bilda sig en uppfattning av det som fältet erbjuder.

Flera artiklar i detta temanummer presenterar eller ger exempel på konkreta och empiriska utvärderingsstudier. Huvudavsikten med en presentation av empiriska studier har varit att försöka fånga in hur utvärderingsforskare gjort när de säger att de utvärderat en insats eller ett program. Exempel på empiriska studier utgör, enligt min mening, ett pedagogiskt sätt att utveckla sin egen utvärderingspraktik. Genom att studera andras studier kan man lära sig undvika misstag och förbättra sitt eget arbete.

I temanumret ingår även ett urval av artiklar som var och en presenterar det som jag uppfattar som utvärderingsforskningens spetsfrågor, internationellt sett. Det är viktigt att komma ihåg att detta bara är ett urval. Spetsfrågor som internationellt debatteras och forskas om är huvudsakligen av metodologisk karaktär snarare än paradigmatisk. De paradigmatiska frågorna återkommer oftast i (begränsade) debatten om utvärdering som disciplinär verksamhet eller i modelltänkandet vilket är mycket utbrett i utvärderingsforskningen. Spetsfrågorna återfinns huvudsakligen i metod- och metodologisk utveckling. Några exempel är frågor som berör datainsamling, effektmätning, validitet, itemvaliditet, systematiska forskningssynteser och forskningsanvändning.

Temanumret börjar med en artikel av Michael Scriven (USA) som uppfattar utvärderingsforskningen som en egen disciplin. Närmare bestämt är utvärderingsforskning en "transdisciplin " som statistik och matematik. Transdiscipliner är analytiska verktygsdiscipliner med egen plattform. Scriven har utvecklat dessa tankar under en längre tid men började först publicera dessa under 1990-talet. 
Den föreliggande artikeln har tidigare varit publicerad i Scandinavian Journal of Social Welfare år 1998. Det är nu efter några år intressant att konstatera att Scrivens ansats fortfarande står oemotsagd, men också utan att någon på allvar följt spåren för vidareutveckling av ansatsen.

Evert Vedung (Sverige) presenterar en översiktlig bild av utvärderingsmodeller. Med en historisk blick typologiserar han utvärderingsmodeller efter grundläggande värdekriterier. Hans exempel kommer från olika policyområden inklusive naturvetenskapligt inriktade områden som skogsvård och miljöproblem. Även om exemplen inte är lånade från det sociala arbetets fält visar Vedungs exempel att det i princip är samma sorts designproblem och mätproblem som utvärderingsforskarna måste lösa inom olika interventions- och policyområden.

Ian Shaw (Storbritannien) har under senare år varit en framgångsrik förespråkare för användning av kvalitativa metoder $\mathrm{i}$ utvärdering av praktiskt socialt arbete. I sin artikel fortsätter han i samma bana för att argumentera för fördelarna med kvalitativa metoder när man utvärderar socialt arbete. Hans anspråk på kvalitativa metoders förmåga att hantera kausalitet är särskilt järvt. Han presenterar också ett konkret fall av utvärdering av socialt arbete i Storbritannien.

Med ökat intresse för studier av interventioners effekter har frågor kring utfall och utfallsmått åter blivit aktuella. Utfall är avsedda och icke-avsedda förändringar hos enheter till följd av påverkan från sociala interventioner. I denna artikel beskriver Haluk Soydan ochBo Vinnerljung (Sverige) några av de problem som de mött $i$ utvärde- ringsverksamhet.

Av olika skäl - till exempel för att fånga in empiriska variationer eller att säkra ett större empiriskt material - har man särskilt i USA utvärderat interventioner eller program på flera orter (»sites«) parallellt. Edward Mullen (USA) som har många års erfarenhet av flerortsstudier presenterar en rik flora av utvärderingsstudier som genomförts i USA. Han utvecklar en intressant typologi som systematiserar olika former och typer av flerortsutvärderingar.

Under ett par decennier har avancerade metaanalyser genomförts som underlag för upplyst beslutsfattande i professionell praktik och policyutveckling. Metanalys är ett samlingsbegrepp för statistiska metoder för genomförande av systematiska forskningssynteser. Mark Lipsey (USA), som spelar en ledande roll i denna utveckling presenterar grunderna för metanalys. Han sammanfattar också metodologiska erfarenheter från ett stort antal metaanalyser. Dessa ökar kraftigt vår insikt $i$ effektstudiers styrka och svagheter.

Anthony Petrosinos (USA) bidrag utgör ett kompletterande inslag till metanalyser. Petrosino följer upp tidigare spår och argumenterar för en integration av metaanalytiska ansatser med programteoriutvärdering. Medan den förra ansatsen avser systematisering av resultat från flera utvärderingar avser det senare studium av underliggande antaganden och mellanliggande variabler i ett interventionsprogram vilka anses bidra till förståelsen av varför programmet borde »fungera .

Individer utgör den traditionella allokeringsenheten i randomiserade studier. Det kan finnas flera skäl, inte minst etiska, att

Socialt arbete och utvärdering 
inte använda individer som allokeringsenhet. I denna artikel för Robert Boruch (USA), Ellen Foley (USA) och Jeremy Grimshaw (Canada) fram möjligheten att använda andra enheter i radomiserade studier. Sådana enheter kan vara geopolitiska »ställen« som grannskap, polisdistrikt, skolor såväl som administrativa enheter och grupper av individer. Denna typ av randomisering kallas också grupprandomisering eller klusterrandomisering. Författarna är mycket generösa med att beskriva flera utvärderingsstudier där klusterrandomisering använts.

Kari Jess och Siv Nyström (Sverige) sammanfattar erfarenheter av och resultat från en svensk kvasi-experimentel utvärderingsstudie, Krami-studien. I artikeln rapporterar de dels en klientstudie, dels en samhällsekonomisk studie av de studerade rehabiliteringsprogrammen. KrAmistudien är intressant inte bara på grund av sin för svenska förhållande sällsynta design, men också för de positiva effekter som Krami-programmet tycks ha på sina klienter.

Slutligen publicerar vi i temanumret personliga reflektioner av Bengt-Åke Armelius (Sverige) kring den historiska utvecklingen om hur psykoterapin successivt baserats på empiriskt prövade kunskaper. Med referens till debatten om möjligheterna att införa systematiska utvärderingar och empiriskt dokumenterade kunskaper som grund för åtgärder och beslut inom socialtjänsten känner han igen mycket av de argument och de känslor som uttrycks i den allmänna debatten från den tid då man inom den kliniska psykologin började med psykoterapiforskning.

Avslutningsvis några ord om språken $\mathrm{i}$ artiklarna. Ett flertal av artiklarna har skrivits av engelskspråkiga författare för att sedan översättas till svenska av utomstående översättare i Sverige. Redaktionsmedlemmar, redaktionssekreteraren och gästredaktören har satsat åtskilliga timmar för att granska såväl fackterminologin som svenskan i dessa artiklar. Trots detta är vi inte nöjda med översättningarna. Vi har valt att publicera fyra artiklar i originalspråket, engelska. Svenska översättningarna av dessa artiklar finns på tidskriftens hemsida, www.forsa.nu.

Stockholm, september 2002

Haluk Soydan

Gästredaktör

Centrum för utvärdering av socialt arbete, och

Stockholms universitet

\section{Litteratur}

Franke-Wikberg, Sigbrit, Lundgren, Ulf (1980). Att utvärdera undervisningen. Del I. Stockholm: Wahlström \& Wistrand.

Oakley, Ann (2000). Experiments in Knowing. Gender and Method in the Social Sciences. New
York: The New Press.

Macdonald, Geraldine (1998). »Promoting evidence-based practice in child protection « Clinical Child Psychology and Psychiatry, 3 (1), 71-85. 
McCord, J. (1978). »A thirty-year follow-up of treatment effects « American Psychologist, March, 284-289.

Scandinavian Journal of Social Welfare: Special Issue - Evaluation Research and Social Work (1998). (7) 2

Socialstyrelsen (2000). Nationellt stöd för kun- skapsutveckling inom socialtjänsten. SoS-rapport 2000:12.

Vedung, Evert (1991). Utvärdering i politik och förvaltning. Lund: Studentlitteratur.

Vedung, Evert (1997). Public Policy and Program Evaluation. New Brunswick: Transaction Publishers.

TACK: Föreliggande temanummer har krävt avancerat administrativt arbete över nationsgränser och ovärderligt stöd till gästredaktören. Jag tackar forskningsassistenten Johan Glad för hans noggranna och effektiva arbete. 